\title{
Framing Analysis of Belt and Road Initiative Coverage in Major Nigerian, Malaysian, and Vietnamese Newspapers
}

\author{
Uchenna Kingsley Anunne, \\ Pham Ngoc Phuong Thuy, \\ Julia Tan Yin Yan, \\ Prof. Yan Lifeng, PhD
}

School of Journalism and Communications, Xiamen University,Siming South Road, Fujian, China

Doi:10.19044/esj.2019.v15n29p1 ～URL:http://dx.doi.org/10.19044/esj.2019.v15n29p1

\begin{abstract}
In 2013, Chinese president, Xi Jinping, announced the Belt and Road Initiative (BRI) to his audience in Kazakhstan. He stated that this will involve the construction of roads, railways, and even special trade corridors, among others along the ancient Silk Road in a bid to foster economic, political, and social relationship between China and partner countries. This paper focuses on analyzing how leading newspapers in Nigeria, Malaysia, and Vietnam, namely The Sun, Vanguard, The Punch, The Nation, New Straits Times, Malay Mail, Business Insider, The Star, Saigon Times and Vietnamnet Bridge, have framed and communicated this multi-national project to their various audiences six years after Xi's announcement. Working on 200 editorial contents published between May 2017 and March 2019 across the selected newspapers, this explores how they framed BRI. We found that while most of the reports have framed BRI positively, others are framed to reflect cautious optimism. We suggest that BRI managers should take necessary steps to engage the media, policy makers, and other stakeholders to properly educate them on the vision and mission of the initiative.
\end{abstract}

Keywords: BRI framing, Economic corridor, Mutual benefit

\section{Introduction}

At Nazarbayev University, Astana, Kazakhstan, in 2013, President Xi Jinping, unveiled the Belt and Road initiative (BRI). He said the multibillion dollar initiative was meant to boost infrastructure, create employment, enhance economic growth, and promote people-to-people exchanges among 
subscribing nations. BRI was part of the Resolution of the Third Plenum of the $18^{\text {th }}$ Committee of the Chinese Communist Party. Thus, the document encapsulates China's drive for comprehensive reforms.

The BRI aims to follow ancient Silk Road, a major trading route between China and other parts of the world, connecting countries along the route with roads, bridges, railways, as well as creating special trading and commercial corridors. It involves no fewer than 65 countries and 900 projects with investment estimated at $\$ 850$ billion. The bulk of the project is being funded with a $\$ 100$ billion startup domiciled at Asian Infrastructure Investment Bank (AIIB).

By attempting to revamp the Ancient silk road, according to Nalbantoglu (2017), China has demonstrated its understanding of the historical importance of the route in facilitating not only trade between the East and the West but also cultural, political, and social exchanges between the two peoples.

Chen and Zhang (2016) stated that BRI's strategic thinking is "all serve me, I serve all" rather than an attempt by China to economically dominate partnering countries, describing it as an attempt to more effectively integrate global resources and capital. Sarker, Hossin, Yin, and Sarki (2018) opined that by contributing to the economic development of partner countries, BRI could advance international peace.

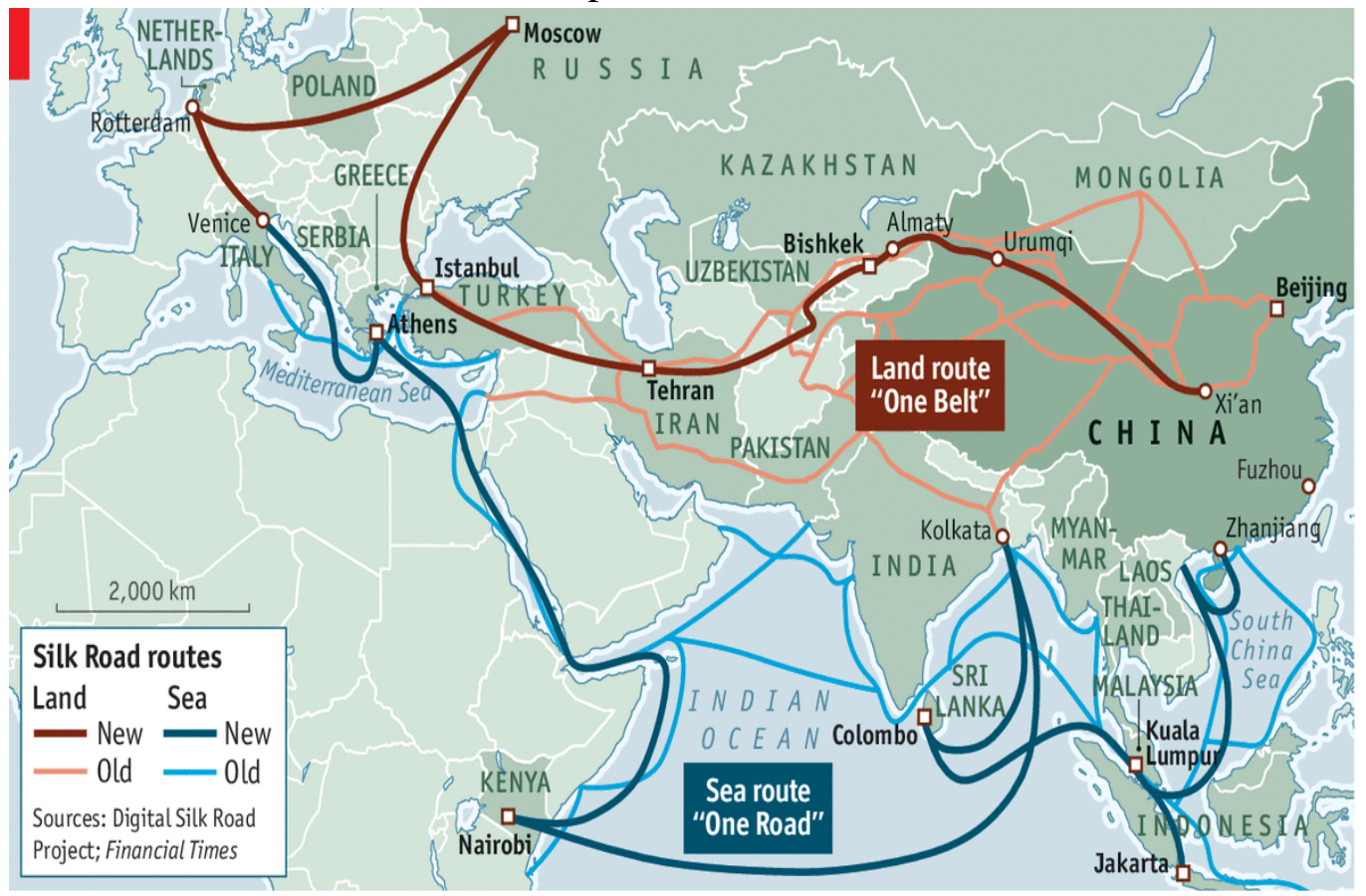

Figure 1. One Belt One Road map. Source: The Economist 
However, BRI faces some criticisms one of which Peter (2017) alleged that BRI's main objective is to help China in achieving geopolitical goals by economically binding her neighbors more closely to Beijing. Ivan (2015) says China has to do more to convince other countries that BRI is a force for good by being more transparent in pushing the BRI agenda. Despite criticisms, Seesaghur (2016) is optimistic that the initiative will facilitate China's efforts to coordinate with other nations, provide financial integration, expand trade liberalization, and contribute to strengthening people-to-people connectivity.

\section{Literature Review}

Since Xi unveiled BRI, it has been under media scrutiny. As the international media coverage grows, so does its scholarly investigation. Tran (2018), in one of such studies, found that media framed the BRI to be mutually exclusive to China and her partners. The study, which focused on Radio China International and Voice of Vietnam, observed that while the Chinese broadcaster framed BRI as China's effort to promote regional integration, the Voice of Vietnam framed the Initiative having considerable potential for the Vietnamese economy.

Similarly, Tai (2018) examined the different lenses through which BRI is viewed. This included the media narrative and concluded that in many instances, the media had reported it with optimism. It is considered as a project that would be beneficial to both mainland China and Taiwan on the one hand and the other partners in general on the other hand.

In a study on the place of BRI in China's profile in international politics and diplomacy, Huang (2018) found that the media framed it in a manner that has helped to improve China's image in India and Pakistan by avoiding minimizing expressions that invoke skepticism.

Zhang and $\mathrm{Wu}$ (2017) found that sometimes, in reporting BRI, western media tried to portray China to be forceful and domineering. In a study which compared the BRI coverage between China Daily and Financial Times, the scholars posited that in some instances, Financial Times portrayed China as a fearful empire to be wary of.

Qian (2018) advised that China should engage the international media in more positive ways to tell BRI's story without any bias. In a study, "China's Belt and Road Initiative Through the Lens of Central Asia," Roman and Overland (2019) stated that the media's presentation of BRI had not altered the perception of China in Central Asian countries. The countries covered in the study include Kazakhstan, Kyrgyzstan, Tajikistan, Uzbekistan, and Turkmenistan. As acknowledged, a substantial portion of the BRI projects will be located in Central Asian countries. This, however, does not change the fact that the image of China, as projected by the media, was dated mainly back to 
the early 1990s when the most of the countries emerged from the defunct Soviet Union.

\section{Research Method and Scope}

This study used a quantitative approach to examine BRI coverage by online editions of major newspapers in Nigeria, Malaysia, and Vietnam. In Nigeria, the authors surveyed are The Nation, The Sun, Vanguard, and The Punch. Malaysian newspapers are the New Straits Times, Malay Mail, Business Insider, and The Star. For Vietnam, we studied Saigon Times and the Vietnamnet Bridge. Together, we studied ten newspapers involving over 200 editorial contents. Grouping the total number of editorial contents on BRI, materials in three categories, positive, negative and neutral, the authors seek to determine how most of the reports framed the initiative. Using keywords such as OBOR 'One belt one road initiative', 'China's belt and road initiative', 'belt and road', 'One belt and one road' and 'BRI', the authors identified BRIrelated editorial contents through their headlines and full texts.

Editorial content was considered neutral if the writer presented the BRI without injecting his or her views. On the other hand, a publication was considered negative if the author imposed negative views or opinion on the item. It was regarded as positive if it was framed and delivered in a manner that portrayed BRI in a positive light. The percentage representation of each of the sub-groups was captured using Statistical Program for Social Sciences (SPSS) software. The papers studied were selected based on their popularity in their respective countries of publication. Thus, they were published in English language. This study covers the period May 2017 to March 2019, which falls within the peak of mobilization of international support and resources following the 2017 BRI summit in Beijing.

\section{Purpose and Significance of Study}

This study aims to analyze the selected BRI publications i.e., the positive, negative or neutral presentation of the initiative. Understanding the framing provides an insight into how audiences perceive BRI, given the public opinion-shaping role of the media. We are curious about the media perception of the project in three countries across two continents. However, this led to the process of offering a simultaneous media assessment of the project in a single research. It not only enriches scholarly debate about the project but underscores the need for similar studies on media and public perception of multi-national projects being undertaken by governments.

\section{Theoretical Framework}

Framing reveals how media practitioners influence their audience's reaction to news and events. Some communications scholars argue that 
through framing their news, the media tend to make some issue salient. Therefore, as Scheufele (2004) puts it, framing stresses particular objects and relations.

Citing Shoemaker and Reese (1996), Scheufele and Tewksbury (2007) posited that framing implies the modes of presentation of information that resonates with existing underlying schemas among their audience. This lends credence to the argument that framing works with existing biases in the mind of the audience. In framing, the communicator uses many approaches as he attempts to influence the audience (Moy, Tewksbury, \& Rinke, 2016). They include phrases, images, analogy, or even metaphors. According to them, framing is crucial because it can influence how news audiences think about public affairs. This is because 'frames have the potential to exert substantial influence on public opinion'.

As a property of a message, a frame limits or defines the message's meaning by shaping the inferences that individuals make about the messages (Hallahan, 1999). Frames reflect judgments made by the messages' creators or famers.

In objection, Cacciatore, Scheufele, and Iyengar (2016) picked holes in a manner where framing has overlapped with other theories such as priming. They were of the view that the overlap had left scholars with an incomplete understating of framing concept both in terms of its theoretical boundaries and methods of operationalization. They argued that 'The ambiguity around the concept begins with a lack of consistency around how the concept is defined or how these definitions connect with the explanatory models underlying the theory'.

According to Borah (2011), this convergence of different perspectives has created some form of fuzziness, avoidable by following strict operationalization of what framing is and what it is not.

However, Ardevol-Abreu (2015) posits that framing is an essential communication tool because it draws attention to some aspects of reality at the expense of others. Some communication scholars say framing is always present in the mind of the communicator as the news is written, processed, and delivered to the audience. Zhang and Boukes (2019) posit that frame-setting processes and their effects are particularly influential in news reports about foreign nations because ordinary domestic audiences have little knowledge about international affairs. This holds lots of implications for BRI.

\section{Data Analysis}

In Nigeria, with 39\%, The Nation had the highest number of BRIrelated reports while Vanguard, The Sun, and The Punch had 26\%, 19\%, and $16 \%$ of the total 31 materials respectively within the period covered by this 
study. The study found that $58 \%$ of reports positively portrayed BRI, while $26 \%$ are neutral and $16 \%$ framed negatively.

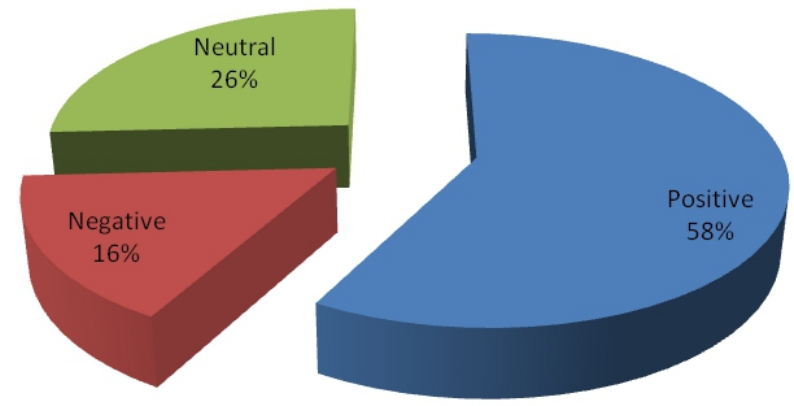

Figure 2. Positive, negative, neutral percentage share of Nigerian newspaper

The findings indicate that $59 \%$ of The Nation reports framed it positively, $33 \%$ framed it negatively, and $8 \%$ were neutral. For instance, on 30 April, 2018, The Nation ran a story titled: One belt, one road policy can boost Nigeria's economy; Nigeria, China to sign $\$ 328 \mathrm{~m}$ agreement on ICT. The Nation, 2 September, 2018, expressed what Nigeria stands to benefit from being BRI. Other positive reports include: Why we are interested in doing business with Nigeria, The Nation, 7 July 2018; \$20m investment excites Ambode (The governor of Nigeria's Lagos State), The Nation, 13 May 2018. Some of the negatively framed reports included a copy published in The Nation, 23 August, 2018, under the headline: China an adversary, says Pentagon. The report warned countries of the negative security implications of joining BRI. A similar negative material was published in The Nation, 29 July, 2017 under the headline: Sri Lanka signs port deal with China. The material warned that a deal on Hambantota port overlooking the Indian Ocean would lead to Sri Lankan being turned into a Chinese colony. Others are: Chinese Silk Road: Debt Peonage for Nigeria, which was published on The Nation, 13 November 2018. It speculated that BRI is a debt trap by China for partner nations. Also, 'Getting yourself out of the Chinese quagmire, The Nation 8 April 2018. From the neutral perspective is a report on StanCharts Lists gains of Chinese Currency to Nigeria. The writer of the report did inject personal sentiments but just an account of what transpired at a BRI-related event. 


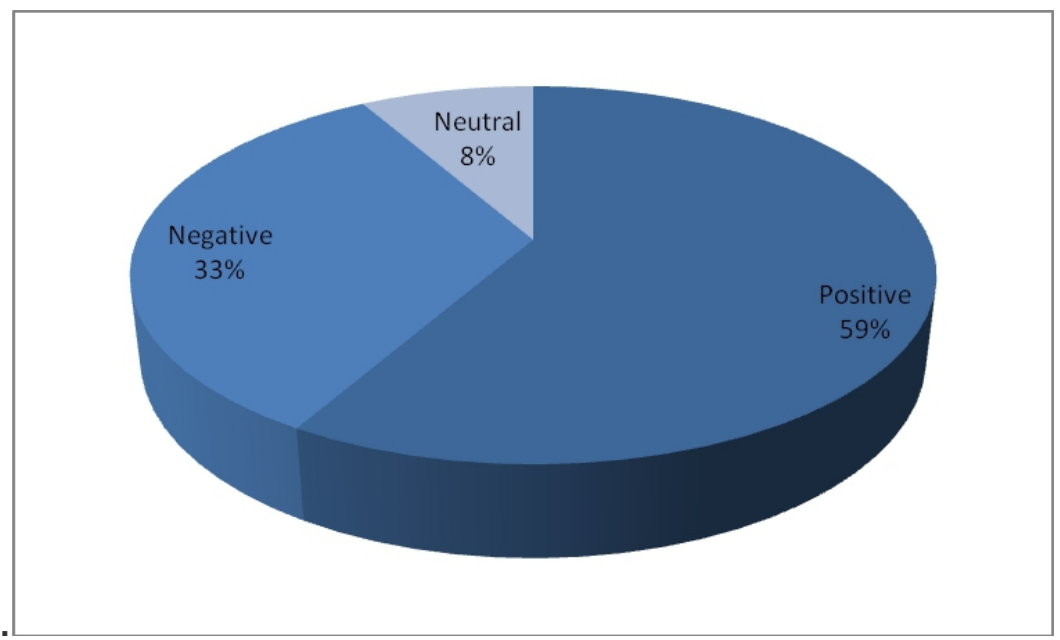

Figure 3. Positive, negative, and neutral percentage representation of materials in The Nation

The results follow a similar pattern in The Punch where $80 \%$ reports framed BRI positively while the remaining $20 \%$ were negative. Curiously, none of the reports was neutral.

On the positive frames are: China's belt initiative and making of new world order, The Punch, 23 May 2017. It argued that BRI aimed at advancing economic globalization and cultural diversity. Another one, 'Nigeria, others' ill gain from US-China trade war', The Punch 17 October 2018, projected BRI as an opportunity to upgrade infrastructure in many countries rather than a neo-colonial tool. Other positively framed reports includes 'No strings attached to investment in Africa,' says China's Xi, The Punch, 3 September 2018; and Nigeria, China set to sign \$328m ICT agreement, The Punch, 2 September 2018.

On the negative side is: Everyday for the borrower, one day for the creditor, a 10 September, 2018 report in The Punch which centered on the debt implication of the BRI on poor partner-countries.

None of the BRI publications in the Vanguard was framed negatively. 63\% per cent of BRI-related reports were neutral, while the remaining $37 \%$ per cent were positive. On the positive side is: The belt and road: new opportunities for China-Nigeria cooperation a Vanguard, 28 March, 2017, a report which framed BRI as an opportunity for Nigeria to form a mutually benefiting partnership with China. See also: The belt and road initiative: equal and inclusive development, Vanguard, 7 June 2017; Africa has chosen China, say Burkina Faso president, Vanguard, 29 August 2018.

The neutral materials include: Nigeria, China to sign $\$ 328 \mathrm{~m}$ agreement on ICT, Vanguard, 1 September, 2018; China says new Silk Road not about 
military ambition, 25 May 2017, China's Xi says no strings attached to African investments, which was published in the Vanguard, 3 September 2018.

Just like Vanguard, none of the reports in The Sun framed the initiative negatively. Rather, they either constructed it positively or they chose neutrality. But unlike the Vanguard at 67\%, The Sun reports are framed positively, while $33 \%$ of them are neutral. In a report in The Sun on 16 March 2018 under the headline, Nigeria and China's one belt, one road initiative, the author framed BRI as capable of promoting shared interests. Other positively framed reports include: Nigeria and China's belt and road initiative, The Sun, 28 March 2018; When belt and road forum ushered in new economic order, The Sun, 13 June 2017; China's Maritime Silk Road, game changer for global transport, The Sun, 12 November 2018; UNICEF cooperate with China through belt, road initiative, The Sun, 15 May 2017. On the neutral side, the reports include: China urges Nigeria to tap into $\$ 43.5 \mathrm{bn}$ Silk Road fund, The Sun, 25 May 2017.

The framing follows a similar pattern in Malaysian newspapers where $60 \%$ of the 85 BRI-related publications framed it positively. New Straits Times leads with the number of positive stories. However, all the five The Business Inside's stories were framed negatively. On the positive side are: World should Support Initiative, written by Patrick Teh, New Straits Times, 1 June 2017; China's one belt one road initiative; Strengthening Economic Linkages for Mutual Benefit, New Straits Times, 1 May 2017; Malaysia to grow by 6 per cent in 2017: UBS Bank, by Rupa Damodaran, New Straits Times, 24 December 2018; and ASEAN will reap benefits from Chinese benefits from Chinese investments in the region, by Nurul Hazren Masitom, New Straits Times, 13 November 2017; Malaysia looking to improve ties with China-Dr M, by Bernama, New Straits Times, 15 February 2019; May bank prepares to facilitate substantial deals from China into ASEAN via OBOR, by Lilidiana Rosli, New Straits Times, 27 March 2018.

\section{New Straits Times}

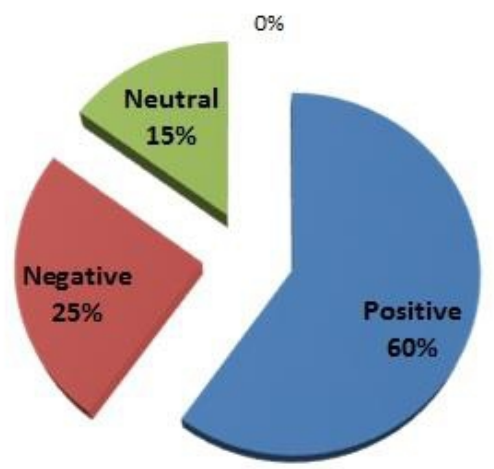

Figure 4. New Straits Times positive, negative and neutral share of materials 
Malay Mail had 25\% negatively-framed materials, which includes: China is most influential in SE Asia, but has little trust, Malay Mail 7 January 2017; China must not 'colonize' Italian businesses, Says League Party. Malay Mail, 12 March 2019 which highlights fears of the party at moves by the Italian government to sign up to BRI; and Making Waves in West, China luring Pacific Islands with Belt and Road, Malay Mail, 15 November 2018. On the positive side include Surging ahead with One Belt, One Road-Sin, Malay Mail, 17 May 2017; Malaysia 'committed to being part of One Belt, One Road initiative, says minister; Malay Mail 8 March 2018; Malaysia 'very open for business with China, says deputy trade minister, Malay Mail 28 February 2019.

The study further showed that Business Insider does not consider BRI's positive framing to be advantageous. The following publications, among others, are entirely negative: China's massive belt and road spending spree has caused concern around the world, and now it's China's turn to worry, by Christopher Woody Business Insider, 3 July 2019; 'Australia's New prime minister sounds like he wants to take on China's growing influence in the South Pacific', by Christian Edwards, Business Insider, 8 November 2018, a news story in which the PM Scott Morrison neither mentioned China nor BRI; Malaysia has axed $\$ 22$ billion of Chinese-backed projects, in a blow to China's grand plan to dominate world trade, by Alexandra Ma, Business Insider, 21 August 2018. This search did not yield any story that celebrated BRI or showed an independent mind both in text and headlines.

Conversely, based on majority of The Star materials, $58 \%$ of them portrayed BRI positively, 25\% negatively framed stories, while the remaining $17 \%$ were neutral. Among the neutrals are: We need greater cooperation, says XI, The Star 16 May 2017; China's new 'Silk Road' cannot be one-way, France's Macron says; Understanding China's vast market, written by Lo Tern Chern The Star 8 March 2018; Trade forum to focus on one belt one road The Star 11 January 2018.

The positive publications in The Star include: Better days ahead for economy, The Star, 2 February 2018 publication which projects that with BRI, the Malaysian economy is on the right track to greater heights; OBOR initiative offers vast opportunities, The Star 22 July 2018; Belt and Road effort a boost for Malaysia, The Star, 16 January 2018; China's belt and road initiative will be key catalyst for outbound investment flows, The Star, 9 June 2017; Why Malaysia supports China's belt and road initiative, The Star, 12 May 2017. The negative side include: No Chinese belt, road or bedrooms for Malaysia, The Star, 30 August 2018; China tells the world bedtime stories in propaganda drive, The Star, 13 May 2017 


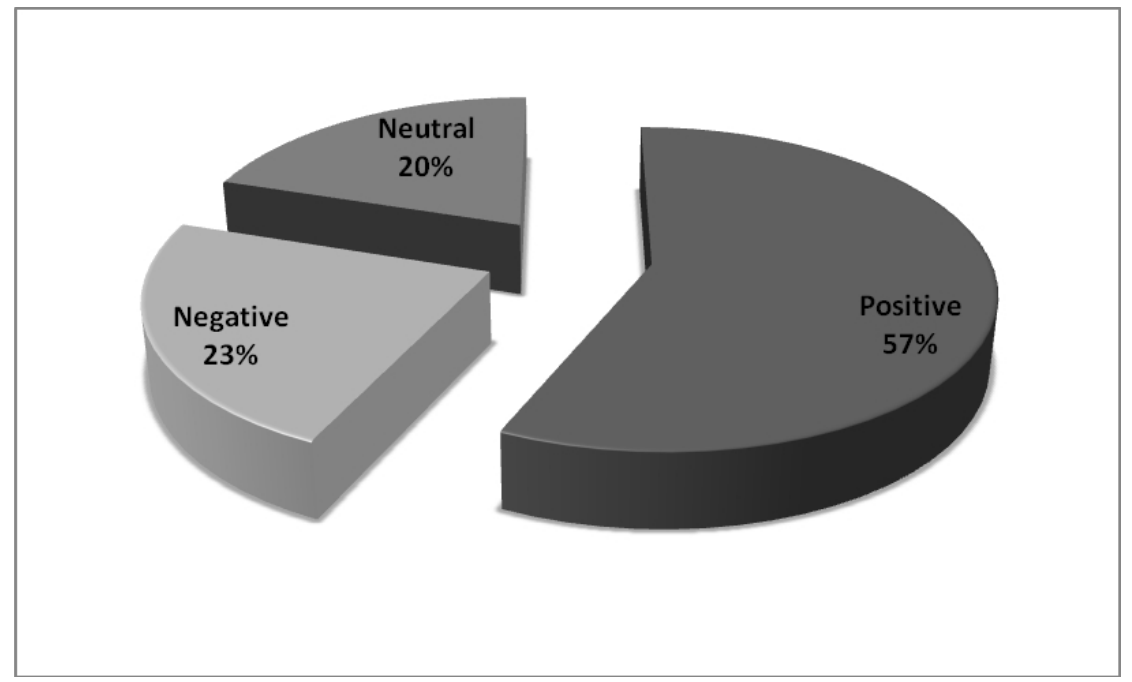

Figure 5. Malaysian newspapers share of positive, negative and neutral materials

The Vietnamese newspapers covered in this study, namely Saigon Times and Vietnamnet Bridge, both published in English language, framed their reports to reflect cautious optimism.

Six of the 12 BRI-related materials carried by Saigon Times, within the period under review, portrayed OBOR negatively. For instance, on 7 January 2019, Saigon Times ran a story titled 'Southeast Asia wary of China's Belt and Road Initiative, Skeptical of U.S', a report which warned that: 'Southeast Asian countries should be cautious in negotiating with China on its flagship Belt and Road Initiative (BRI) to avoid being trapped in unsustainable debt'. Another of such headline is 'Wary of China's rise, Pompeo announces U.S. initiatives in emerging Asia', Saigon Times, 31 July 2018. Similarly, the story under the headline 'U.S pledges nearly US $\$ 300 \mathrm{~m}$ on security funding for Southeast Asia' Saigon Times, 4 August 2018, shows that BRI is a tool to expand Xi's political clout rather than a genuine infrastructure initiative.

However, some publications were not so critical but were rather framed positively. Some of them are: Saigon Times, 6 April 2018 'HSBC: Business optimistic about international trade prospects' by Phuong Thao, which predicted that Vietnamese economy will benefit immensely from BRI;

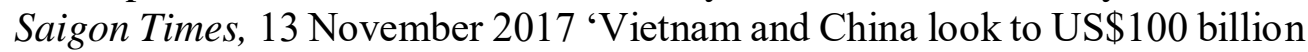
trade', by Truc Diem which said BRI was part of this trade deal aimed at boosting Vietnamese economy through Vietnam-China cooperative corridors; and Saigon Times, June 1, 2017 'Private sector key driver to Vietnam's economic growth'. This report also portrays BRI as a potential major contributor Vietnamese private sector development. U.S.-China divisions dominate APEC Summit. The Saigon Times Daily, 17 November 2018 is one of the neutral publications. 


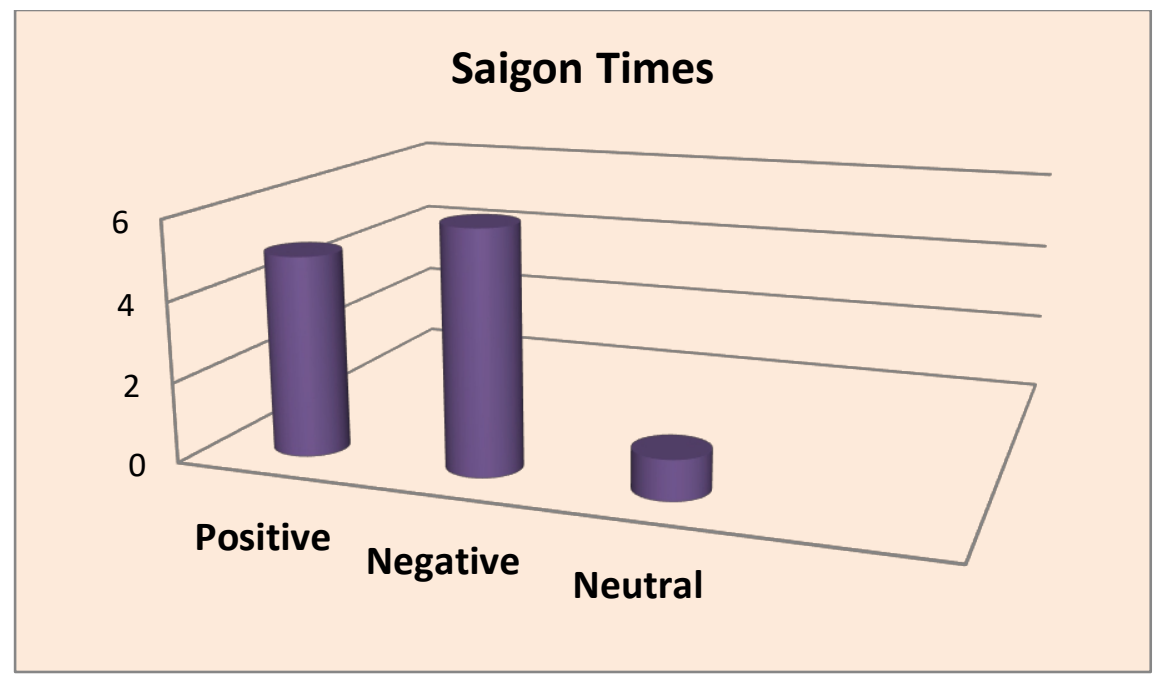

Figure 6. Saigon Times share of positive, negative and neutral share of publications

Investigation in the Vietnamnet Bridge shows that the online newspaper was also positively cautious in reporting BRI. For instance, on 7 October 2017, the newspaper under the headline: 'Trade carefully on China's belt and road initiative: experts' urged that "nations should look beyond mere economic gains and consider questions of sovereignty and excessive dependence when considering participation in China's belt and road initiative." So also is the story published under the headline "Vietnam welcomes Chinese investment capital but remains wary of risks,' Vietnamnet Bridge, 4 April 2018. However, some other reports framed BRI positively such as Vietnamnet Bridge 25 August 2017 under the headline: China, Vietnam discuss belt and road initiative' which framed BRI as a boost for regional integration and infrastructure development.

See also, 'Chinese capital keeps heading for Vietnam', Vietnamnet Bridge published on 7 February 2018, which opined that BRI has further opened the doors for more Chinese investment to inflow to Vietnam.

\section{Conclusion}

This study BRI is framed positively in the surveyed newspapers, highlighting its economic and infrastructural development importance. This is similar to optimism expressed by Mwatela and Zhao (2016) who argued that for Africa, specifically, BRI provides a win-win-situation as Africa, in dire need of infrastructure, will benefit from the investment offered under the initiative while China will also benefit by using the corridor to advance its market into Africa. 'BRI is a sustainable continuation development of the long term traditional and cultural convergence with Silk Road countries,' say Kang, 
Peng, Zhu, and Pan (2018). Most of the studied newspapers seem to align with this view.

However, skepticisms continue about China's sincerity. It is suggested that BRI handlers should address themselves to finding answers to disarm opponents, getting the right narratives across, and winning its 'enemies' from 'imperialism and neocolonialism narratives (Sidaway \& Woon, 2017). Convincing the world that BRI is a force for good is one responsibility the Chinese authorities must meet because it is key to the success of the initiative (Shih-Chih, Jianing, \& De, 2018). Achieving that requires China to reach out to participating nations towards ensuring that it got the necessary coordination, policy support, and incentives as well as legislations required for BRI's success.

\section{Conflicting Interests}

The authors declare that they have no conflicting interests.

\section{References:}

1. Adegbemle, A. (2018). Getting yourself out of Chinese quagmire. The Nation, 8 April. Retrieved from

http://thenationonlineng.net/getting-chinese-quagmire/

2. Africa has chosen China, says Burkina Faso President. Vanguard, 29 August, 2018.

Retrieved from https://www.vanguardngr.com/2018/08/africa-has-chosenchina-says-burkina-faso president/

3. Ardevol-Abreu, A. (2015.). Origins, development and current situation in Spain: Framing theoryin communication research, origins, developments and current situation. Revista Latina de Communication Social, Vol. 70 pp. 423-450

4. Asu, F. (2018). Nigeria, others 'll gain from US-China trade war. The Punch, 17 October 2017. Retrieved from https://punchng.com/nigeriaothersll-gain-from-us-china-trade-war

5. Borah, P. (2011). Conceptual issues in framing theory: A systematic examination of a decade's literature. Journal of Communication, Vol. 61. No. 2. Pp. 246-263

6. Better days ahead for economy. The Star, 2 February 2018. Retrieved from https://www.thestar.com.my/metro/metronews/2018/02/02/better-days-ahead-for-economy-experts-sharepredictions-on-local-and-global-trends-at-property-forum/

7. Belt and road effort a boost for Malaysia. The Star 16 January 2018. Retrieved https://www.thestar.com.my/metro/metronews/2018/01/16/beltandroad-effort-a-boost-for-malaysia-talk-atmenara-star-on-thursday-a-chance-to-explore-business/ 
8. Belt and Road Initiative: Equal and inclusive development. Vanguard, $7 \quad$ June, $2017 . \quad$ Retrieved from https://www.vanguardngr.com/2017/06/the-belt-and-roadinitiative-equal-and-inclusive-development/

9. Belt, Road: New Opportunities for China-Nigeria cooperation. Vanguard, March 28 , 2018. Retrieved from https://www.vanguardngr.com/2017/03/beltroad-new-opportunities-china-nigeria-cooperation/

10. Cacciatore, M.A., Scheufele, D. A., \& Iyengar, S (2016.) The end of framing as we know it...The future of media effects, Mass Communication and Society. Vol. 17. Pp. 7-23.

11. Chen, L., \& Zhang, W. (2016). China energy resources-oriented OBOR: Research on OBOR growth strategy in China. Basic Research Journal of Social and Political Science. Vol. 4 (1) pp. 01-14

12. China an Adversary, says Pentagon. The Nation, 23 August 2018. Retrieved from http://thenationonlineng.net/china-an-adversary-of-us-says-pentagon/

13. Chendo, K., \& Obaze, O. H. (2018). Chinese Silk Road: Debt peonage for

Nigeria.

The

Nation,

13 November 2018. Retrieved from http://thenationonlineng.net/chin ese-silk-road-debt-peonage-for-nigeria/

14. Chern, L.T. (2018). Understanding China's vast market. The Star , March 8, 2018. Retrieved from https://www.thestar.com.my/metr o/metro news/2018/03/08/understanding-chinas-vast-market/

15. China is most influential in SE Asia, but has little trust, survey shows. Malay

Mail,

7 January 2019. Retrieved from https://www.malaymail.com/news/w orld/2019/01/07/south-east-asia-wary-of-chinas-belt-and-roadproject-sceptical-of-us-survey/1709717

16. China must not 'colonize' Italian business, says League Party. Malay Mail,

March 2019. Retrieved from https://www.malaymail.com/news/mone y/2019/03/12/china-must-not-colonise-italian-business-says-leagueparty/1731624

17. China's belt and road initiative will be a catalyst for outbound investment flows.

The Star 9 June 2017. Retrieved from https://www.thestar.com.my/bu siness/business-news/2017/06/09/china-belt-and-road-initiative-willbe-a-key-catalyst-for-outbound-investment-flows/

18. China's Maritime Silk Road, game changer for global transportNIMASA

DG,

The Sun, 12 November 2018. Retrieved from https://www.sunnewso 
nline.com/china-maritime-silk-road-game-changer-for-globaltransport-nimasa-dg/

19. China says new Silk Road not about military ambition. Vanguard, 25 May 2017. Retrieved from https://www.vanguardngr.com/2017/05/china-says-new-silk-roadnot-military-ambitions/:

20. China tells the world bedtime stories in propaganda drive, The Star, 13 May,

Retrieved from https://www.thestar.com.my/news/regional/2017/05/1

3/china-tells-the-world-bedtime-stories-in-propaganda-drive

21. China's new 'Silk Road' cannot be one-way, say France's Macron.

The

Star,

8

January 2018. Retrieved from https://www.thestar.com.my/news/worl d/2018/01/08/chinas-new-silk-road-cannot-be-oneway-francesmacron-says/

22. China's Xi says no strings attached to Africa investments. Vanguard, 3

September

2018. Retrieved from https://www.vanguardngr.com/2018/09/chinasxi-says-no-strings-attached-to-africa-investments/

23. Chinese capital keeps heading for Vietnam. Vietnamnet Bridge, 7 February 2018 .

Retrieved from https://english.vietnamnet.vn/fms/business/194869/ch inese-capital-keeps-heading-for-vietnam.html

24. Chong, D. (2019). Malaysia 'very open for business' with China, says deputy

trade minister, Malay Mail 28 February, 2019. Retrieved. https://ww w.malaymail.com/news/malaysia/2019/02/28/malaysia-very-openfor-business-with-china-says-deputy-trade-minister/1727701

25. Damodaran, R. (2017). Malaysia to grow by 6 pct in $2017 ; 5$ pct in 2018: UBS Bank. New Strait Times, 14 December 2018. Retrieved from https:/www.nst.com.my/ business/2017/12/314540/malaysia-grow-6-pct-2017-5-pct-2018-ubsbank

26. Diem, T. (2017). Vietnam and China look to US\$100billion trade. The Saigon Times Daily, 13 November. Retrieved from https://english.thesaigontimes.v n/57021/vietnam-and-china-look-to-us\$100-billion-trade.html

27. Dung. T. (2017). Private sector the key driver of Vietnam's growth. The Saigon Times Daily. June. Retrieved from https://english.thesaigontimes.vn/54253/private-sector-the-key-driver-of vietnam\%E2\%80\%99s-growth.html 
28. Duru, I. (2018). Why we are interested in doing business with Nigeria. The Nation, 7 July 2018. Retrieved from http://thenationonlineng.net/why-we-are-interestedin-doing-business-with-nigeria/

29. Edwards, C. (2018). Australia's new prime minster sounds like he wants to take on China's growing influence in the pacific. Business Insider, 8 November, 2018. Retrieved from https://www.businessinsider.my/australia-wants-to-challengechinese-influence-in-south-pacific-2018-11/

30. Egbe, R. (2018). One Road policy can boost Nigeria's economy, The Nation, 30 April. Retrieved from https://thenationonlineng.net/onebelt-one-road-policy-can-boost-nigerias-economy/

31. Ehikioya, A. (2018). Nigeria, China to sign $\$ 328$ million agreement on ICT. The Nation,

September 2018. Retrieved from http://thenationonlineng.net/nigeriachina-to-sign-328-million-agreement-on-ict-2/

32. Emewu, I. (2017). When Belt and Road Forum ushered in new economic order. The Sun, 13 June. Retrieved from https://www.sunnewsonline.com/when-belt-and-roadforum-ushered-in-new-economic-order/

33. Folasade-Koyi, A. (2017). China urges Nigeria to tap into $\$ 43.5 \mathrm{bn}$ Silk Road fund. The Sun 25 May. Retrieved from https://sunnewsonline.com/china-urges-nigeria-totap-into-43-5bn-silk-road-fund/

34. Hallahan, K. (1999). Seven models of framing: Implications for public relations. Journal of Public Relations Research, Vol. 11 No. 3. Pp. 205242

35. Huang, H. (2018). China's image in the Belt and Road Initiative: case study of Pakistan and India case, being a thesis for the award of Master degree in Asian Studies, Lund University, Sweden

36. Ivan, D.C. (2015). One belt \& One road: Between Cooperation and geopolitics in the Silk Road. Contacto Global, Vol. 6. Pp. 18-25

37. Kang, L., Peng, F., Zhu, Y., \& Pan, A. (2018). Harmony in Diversity: Can the One Belt One Road initiative promote outward foreign direct investment? Sustainab ility.Vol.10No.9.3264;doi:10.3390/su10093264

38. Ma, A. (2018). Malaysia has axed $\$ 22$ billion of Chinese-backed projects, in a blow to China's grand plan to dominate world trade. Business Insider, 21 August 2018. Retrieved from https://www.businessinsider.my/malaysia-axes-22-billion-of-beltand-road-projects-blow-to-china-2018-8/ 
39. Malaysia 'committed to being part of One Belt, One Road initiative, says

minister;

Malay Mail 8 March, 2019. Retrieved from https://www.malaymail.c om/news/malaysia/2019/03/08/malaysia-committed-to-being-part-ofchinas-belt-and-road-initiative-says-de/1730636

40. Malaysia looking to improve bilateral ties with China-Dr M, New Straits Time,

February 2019. Retrieved from https://www.nst.com.my/news/nation/ 2019/02/460464/malaysia-looking-forward-improving-bilateral-tieschina-dr-m

41. Making waves in West, China luring Pacific islands with Belt and Road.

Malay

Mail, 15 November 2018. Accessedon March 22, 2019 from, https:// www.malaymail.com/news/money/2018/11/15/making-waves-inwest-china-luring-pacific-islands-with-belt-and-road/1693655

42. Masiton, N.H. (2017). Asean will reap from China's investment in the region.

New

Strait

Times, 13 November. Accessed March 13, 2018 from https://www.ns t.com.my/news/nation/2017/11/302891/asean-will-reap-benefitschinese-investments-region

43. Moy, P., Tewksbury D., \& Rinke, E.M. (2016).Agenda setting, primi ng, and framing. In Jensen, K. B et al.(Eds). The International Encycl opedia of Communication Theory and Philosophy,John Wiley \& Son s, Inc. https://doi.org/10.1002/9781118766804.wbiect266

44. Mwatela, R. Z., \& Zhao, C. (2016). Africa in China's one belt, one road initiative: A critical analysis. Journal of Humanities and Social Science, Vol. 21 Issue 12. Pp. 10-21

45. Mukherjee, A. (2018). No Chinese belt, road or bedrooms for Malaysia, The Star, 30 August. Accessed on 25 March, 2019 from https://www.thestar.com. my/business/business-news/2018/08/30/no-chinese-belt-road-orbedrooms-for-malaysia/

46. Nalbantoglu, C. (2017). One Belt One Road Initiative: New Route on China's Change of Course to Growth. Open Journal of Social Sciences (5) $87-99$

47. Nigeria, China set to sign $\$ 328 \mathrm{~m}$ ICT agreement. The Punch, 2 September 2018. Retrieved from https://punchng.com/nigeria-chinaset-to-sign-328m-ict-agreement/

48. Nigeria, China to sign $\$ 328 \mathrm{~m}$ agreement on ICT. Vanguard, 1 September 2018. Retrieved from https://www.vanguardngr.com/2018/09/nigeria-china-to-sign-328magreement-on-ict- 
49. No strings attached to Africa investments, says China's Xi. The Punch 3 September 2018. Retrieved from https://punchng.com/no-stringsattached-to-africa-investments-says-chinas-xi/

50. Nweze, C. (2018). StanCharts lists gains of Chinese currency to Nigeria, others. The Nation 3 November, 2018. Retrieved from http://thenationonlineng.net/stancha rt-lists-gains-chinese-currency-nigeria-others/

51. Obioha, R. (2018). Nigeria and China's one belt, one road initiative. The Sun, 16 March. Retrieved from https://sunnewsonline.com/nigeria-and-chinas-one-belt-one-roadinitiative

52. OBOR initiative offers vast opportunities. The Star 22 March 2018. Retrieved from https://www.thestar.com.my/business/businessnews/2018/01/22/obor-initiative-offers-vast-opportunities/

53. Ogunlade, A. (2018). \$20m investment excites Ambode. The Nation, 13 May, 2018. Retrieved from http://thenationonlineng.net/20minvestment-excites-ambode/

54. Onunaiju, C. (2017). China's belt and road diplomacy. The Sun, 25 May, 2017. Retrieved from https://sunnewsonline.com/chinas-beltand-road-diplomacy/

55. Onunaiju, C. (2017). China's belt initiative and making of new world order. The Punch 23 May. Retrieved from https://punchng.com/chinas-belt-initiative-and-making-of-newworld-order/

56. Onujaiju, C. (2018). Nigeria and China's belt and road initiative. The Sun, 28 March. Retrieved from https://sunnewsonline.com/nigeriaand-chinas-belt-and-road-initiative/

57. Omese, K. (2018). Every day for the borrower, one day for the creditor. The Punch, 10

September. Retrieved from https://punchng.com/every-day-for-theborrower-one-day-for-the-creditor/

58. Permal, S. (2017). China's one road initiative strengthening economic linkages

mutual benefit. New Strait Times, 1 May. Retrieved from https://ww w.nst.com.my/opinion/columnists/2017/05/235414/chinas-one-beltone-road-initiative-strengthening-economic

59. Peter, C. (2017). Understanding China's Belt and Road Initiative. Lowy Institute for International Policy, retrieved from https://www.lowyinstitute.org/pu blications/understanding-belt-and-road-initiative 
60. Qian, X. (2018). One belt one road initiative and China and the Middle East media exchanges. Journalism and Mass Communication. Vol. 8 No. 5. Pp. 239-245

61. Razak, T., \& Seri, D. (2017). Why Malaysia supports China’s belt and road.

The

Star, 12 May, 2017. Accessed on march 102019 from https://www.th estar.com.my/news/nation/2017/05/12/why-malaysia-supports-chinabelt-and-road/

62. Roman, V., \& Overland, I. (2019). China's Belt and Road Initiative through the Lens of Central Asia, in Fanny M. Cheung and Yingyi Hong (Eds.) Regional

63. Connection under the Belt and Road Initiative. The prospects for Eco nomic and Financial Cooperation. London: Routledge, pp. 115-133.

64. Rosli, L. (2018). Maybank prepares to facilitate substantial deals from China into

Asean via OBOR. New Strait Times 27 March, 2018. Retrieved from https:/ /www.nst.com.my/business/2018/03/349951/maybank-preparesfacilitate-substantial-deals-china-asean-obor

65. Sarker, M.N.I, Hossin, M, A., Yin X., \& Sarker M, K. (2018). One belt one road initiative of China: Implication for Future of global development. Modern Economy. (9) pp. 623-638

66. Seesaghur, H.N. (2016). Corridors of Opportunities And Tensions: One Belt, One Road, Wuhan University Center for Economic Diplomacy, retrieved from ht tps://www.researchgate.net/publication/307164197_Corridors_of_Op portunities_And_Tensions_One_Belt_One_Road

67. Scheufele, B. (2004.) Framing-Effects approach: A theoretical and methodological critique. Communications: European Journal of Communication Research, Vol. 29. No 4. Pp. 401-428

68. Scheufele, D.A., \& Tewksbury, D. (2007). Framing, agenda setting, and priming: The evolution of three media effects models. Journal of Communication, 57(1), pp. 9-20

69. Shih-Chih, C., Jianing, H., \& De. X. (2018). One Belt One Road initiative to stimulate trade in China: A counter-factual analysis. Sustainability. Vol.10 (9). 3242.d oi.org/10.3390/su10093242

70. Sidaway, J. D., \& Chih. Y. W. (2017). Chinese narratives on "One Belt One Road" (一带一路) in Geopolitical and imperial contexts. The Professional Geographer. Vol. 69. No. 2. Pp. 1-13. DOI: 10.1080/00330124.2017.1288576 
71. Southeast Asia wary of China's Belt and Road project, skeptical of U.S-Survey.

The Saigon Times Daily, 7 January 2019. Retrieved from https://engl ish.thesaigontimes.vn/65372/southeast-asia-wary-of-chinas-belt-androad-project-sceptical-of-us--survey.html

72. Surging ahead with One Belt, One Road-Sin, Malay Mail, 17 May, 2017. Retrieved from https://www.malaymail.com/news/what-youthink/2017/05/17/surging-ahead-with-obor/1378449

73. Sri Lanka signs port deal with China. The Nation, July 29, 2017. Retrieved from http://thenationonlineng.net/sri-lanka-signs-port-dealchina/

74. Tai, W.L. (2018). The One Belt One Road Narratives, China and the World: Ancient and Modern Silk Road, Vol. 1, No. 1, pp. 1-23

75. The, P. (2017) World should support initiative. New Strait Times 1 June.

Retrieved

from

https://www.nst.com.my/opinion/letters/2017/06/244617/worldshould-support-initiative

76. Thao, P. (2018) HSBC: Businesses optimistic about int'l trade prospect. The Saigon

Times Daily, 6 April. Retrievd from https://english.thesaigontimes.vn /59177/hsbc-businesses-optimistic-about-int\%E2\%80\%991-tradeprospect.html

77. Trade carefully on China's Belt and Road initiative: Experts. Vietnamnet Bridge.

October 2017. Retrieved from https://english. vietnamnet.vn/fms/gove rnment/187870/tread-carefully-on-china-s-belt-and-road-initiative-experts.html

78. Trade forum to focus on One Belt One Road project. The Star, 11 January,

2018. Retrieved from https://www.thestar.com.my/metro/metro new s/2018/01/11/trade-forum-to-focus-on-one-belt-one-road-projectparticipants-can-find-out-more-about-business

79. Tran, S.T. (2018). The communication and interpretation of One Belt One Road by Chinese and Vietnamese media in the perspective of frame analysis - A case study of Radio China

80. International CRI and Voice of Vietnam VOV in comparison. Global Media Journal. Vol. 16. No 30:96. Pp. 1-8

81. UNICEF to cooperate with China through Belt, Road initiative. The Sun,

Retrieved from https://sunnewsonline.com/unicef-to-cooperate-withchina-through-belt-road-initiative/ 
82. U.S.-China divisions dominate APEC Summit. The Saigon Times, 17 November 2018.

Retrieved from https://english.thesaigontimes.vn/64234/us-china-divisionsdominate-apec-summit.

83. U.S. pledges nearly US $\$ 300$ million security funding for Southeast Asia.

The

Saigon 4 August 2018. Retrieved from https://english.thesaigontimes .vn/61746/us-pledges-nearly-us \$300-million-security-funding-forsoutheast-asia.html

84. Vietnam, China discuss Belt and Road initiative. Vietnamnet Bridge, 25

August

2017. Retrievd from https://english.vietnamnet.vn/fms/government/1 85367/vietnam--china-discuss-belt-and-road-initiative.html

85. Vietnam welcomes Chinese investment, but remains wary about risks. Vietnamnet

Bridge, 4 April 2018. Retrieved from https://english.vietnamnet.vn/f ms/business/199878/vietnam-welcomes-chinese-investment-capital-but-remains-wary-about-risks.html

86. Wary of China's rise Pompeo announces U.S. initiative in emerging Asia.

Saigon

Times. 31 July 2018. Retrieved from https://english.thesaigontimes.v n/61624/wary-of-chinas-rise-pompeo-announces-us-initiatives-inemerging-asia.html

87. We need greater cooperation, says Xi. The Star 16 May, 2018. Retrieved from https://www.thestar.com.my/news/regional/2017/05/16/we-needgreater-cooperation-says-xi-leader-urges-nations-to-rejectprotectionism-at-belt-and-road-su/

88. Woody, C. (2018). China's massive 'Belt and Road' spending spree has caused concern around the world, and now it's China's time to worry. Business Insider, 3 July. Retrieved from https://www.businessinsider.my/belt-and-road-spending-andgrowing-debt-cause-for-concern-in-china-2018-7/

89. Zhang, L., \& Wu, D. (2017) Media representations of China: A comparison of China Daily and Financial Times reporting on Belt and Road Initiative, in Cao and $\mathrm{Wu}$ (eds.) Modern Chinese identities at the crossroads. Critical Arts. Vol. 31 No.6. pp. 29-43

90. Zhang, X., \& Boukes, M. (2019).How China's flagship news progra $m$ frames 'the West':Foreign news coverage of CCTV's Xinwen lian bo before and during Xi Jinping's presidency. Chinese Journal of Co mmunication. Doi: 10.1080/17544750.2018.1554593 